See discussions, stats, and author profiles for this publication at: https://www.researchgate.net/publication/287204696

\title{
Genetic analyses on bodyweight, reproductive, and carcass traits in composite beef cattle
}

Article in Animal Production Science · February 2017

DOI: 10.1071/AN15458

CITATIONS

9 authors, including:

Patricia Tholon

Brazilian Agricultural Research Corporation (EMBRAPA)

40 PUBLICATIONS 185 CITATIONS

SEE PROFILE

L.O.C. Silva

Brazilian Agricultural Research Corporation (EMBRAPA)

106 PUBLICATIONS 1,397 CITATIONS

SEE PROFILE
355

Marcos Eli Buzanskas

Universidade Federal da Paraíba, Areia, Brazil

134 PUBLICATIONS 351 CITATIONS

SEE PROFILE

Danisio Munari

São Paulo State University

209 PUBLICATIONS 874 CITATIONS

SEE PROFILE

Some of the authors of this publication are also working on these related projects:

Estratégias e ferramentas para a identificação e uso de genótipos melhoradores na produtividade sustentável da carne bovina View project

Índices de seleção bioeconômicos para a raça Nelore em sistemas de produção do Cerrado e Pantanal (Bioeconomic selection indexes for Nelore cattle in Cerrado and

Pantanal production systems) View project 


\title{
Genetic analyses on bodyweight, reproductive, and carcass traits in composite beef cattle
}

\author{
Bruno Carlos Pires ${ }^{\mathrm{A}}$, Patrícia Tholon ${ }^{\mathrm{B}}$, Marcos Eli Buzanskas ${ }^{\mathrm{A}}$, Ana Paula Sbardella ${ }^{\mathrm{A}}$, \\ Jaqueline Oliveira Rosa ${ }^{\mathrm{A}}$, Luiz Otávio Campos da Silva ${ }^{\mathrm{C}}$, Roberto Augusto de Almeida Torres \\ Júnior $^{\mathrm{C}}$, Danísio Prado Munari ${ }^{\mathrm{A}, \mathrm{D}}$ and Maurício Mello de Alencar ${ }^{\mathrm{B}}$ \\ ADepartamento de Ciências Exatas, UNESP - Univ Estadual Paulista, Faculdade de Ciências Agrárias e \\ Veterinárias (FCAV), Jaboticabal, São Paulo, Brazil. \\ ${ }^{B}$ Embrapa Southeast Livestock, São Carlos, São Paulo, Brazil. \\ ${ }^{C}$ Embrapa Beef Cattle, Campo Grande, Mato Grosso do Sul, Brazil. \\ DCorresponding author. Email: danisio@fcav.unesp.br
}

\begin{abstract}
In beef cattle, growth, reproductive, and carcass traits have been studied for improving productivity and quality of meat products. The aim of this study was to estimate genetic parameters for birth (BW), weaning (WW) and yearling (YW) weights, scrotal circumferences at weaning (SCW) and yearling (SCY), age at first calving (AFC), ribeye area (REA) and back fat thickness (BFT) in order to provide support for the evaluation program of the composite Canchim breed. Data on 12967 (BW), 7481 (WW), 5131 (YW), 1447 (SCW), 1224 (SCY), 1400 (AFC), and 2082 (REA and BFT) animals were analysed using the Average Information Restricted Maximum Likelihood method under an animal model (single and multi-trait analyses). A substantial proportion of the variation in the bodyweights, scrotal circumferences and carcass traits was associated with the additive genetic term indicating that these traits may respond to the selection process. For AFC, a low heritability estimate was observed. Genetic correlations among bodyweights varied from 0.41 to 0.93 . The genetic correlation among scrotal circumferences was 0.91. Important genetic correlations among YW, SCW, and SCY with AFC were observed $(-0.48,-0.61$, and -0.71 , respectively), indicating that indirect responses to selection for these traits would be expected in the age of which the heifers calve. Furthermore, BFT presented an interesting result with calving performance due to the genetic correlation $(-0.69)$ with AFC. Post-weaning weights showed moderate genetic correlations with REA. Many of the traits considered in the genetic evaluation of this breed are genetically correlated in a favourable manner. Genetic improvement through selection is expected for production, reproduction, and carcass traits in Canchim beef cattle.
\end{abstract}

Additional keywords: Canchim breed, genetic improvement, genetic parameters, selection.

Received 18 August 2015, accepted 4 December 2015, published online 20 April 2016

\section{Introduction}

Growth and reproductive traits are included in the selection criteria of breeding programs (Brumatti et al. 2011) due to their economic importance to the beef cattle industry. Enhanced reproductive indices have direct impact on the profitability of the production system, which may act on the longevity of the cows and higher quantity of animals for sale and selection (Krupa et al. 2005). Furthermore, carcass traits are of great interest to producers due to increasing demands for quality in the consumer market (Yokoo et al. 2010).

According to Luchiari Filho (2000), high quality carcasses should have adequate bone : muscle ratio and good fat coverage. Ultrasound measurements of the ribeye area and fat thickness are a non-invasive and affordable technology to evaluate carcass quality. Fat thickness is to some extent responsible for the conservation of physical and organoleptic traits of meat after slaughter and the ribeye area is located in the region of prime cuts
(Meirelles et al. 2010). Beef cattle breeders are concerned about providing suitable nutritional management systems as well as improving the genetic potential of livestock, especially in composite animals such as the Canchim in order to provide better products.

Thus, the aim of this study was to estimate genetic parameters for bodyweights, scrotal circumferences, age at first calving, ribeye area and fat deposition traits in order to provide support for the Canchim evaluation program.

\section{Material and methods \\ Description of the data}

The data contained animals from the Canchim breed $(5 / 8$ Charolais and 3/8 Zebu) and the MA genetic group (derived from mating between Charolais bulls and 1/2 Canchim $+1 / 2 \mathrm{Zebu}$ dams) raised in Brazil. Details of the Canchim breed development 
and management practices have been previously described in detail by Gianlorenço et al. (2003) and Andrade et al. (2008). The Brazilian Association of Canchim Breeders and Embrapa Southeast Livestock provided data on birthweight (BW), weaning (WW) and yearling (YW) weight, scrotal circumference at weaning (SCW) and yearling (SCY), age at first calving (AFC), ribeye area (REA), and back fat thickness (BFT).

The selection index known as 'genetic qualifying', which was developed through the Embrapa-Geneplus program, is used for selecting genetically superior dams and sires (ABCCANEmbrapa-Geneplus 2015). This index is calculated from estimated breeding values for the following traits (with their respective weighting factors in brackets): BW (0.15), maternal ability at WW (0.20), YW (0.30), slaughter conformation at yearling $(0.20)$, and SCY (0.15).

Weaning and yearling ages were on average $236 \pm 27$ days and $502 \pm 79$ days, respectively. Ultrasound measurements were obtained using the Piemedical Scanner 200 Vet with linear transduction of $18 \mathrm{~cm}$ and $3.5 \mathrm{MHz}$, and the ALOKA $500 \mathrm{~V}$ with linear probe of $17.2 \mathrm{~cm}$ and $3.5 \mathrm{MHz}$, which was positioned over the longissimus dorsi muscle in the region between the 12th and 13th rib (Yokoo et al. 2010). The average age for the ultrasound measure was $555 \pm 87$ days. Data on BW was obtained from 1992 to 2012. For WW and YW, data was obtained from 1996 to 2012. For SCW and SCY, the animals were born from 2003 to 2011. For AFC and ultrasound traits, animals were born from 1996 to 2009 and from 2005 to 2012 , respectively.

\section{Contemporary groups}

Data quality control was carried out using the SAS software (SAS 9.3, SAS Institute, Cary, NC, USA). The least-squares method was used to evaluate the environmental effects. Significant effects $(P<0.01)$ were used to define contemporary groups $(\mathrm{CG})$. Animals without pedigree information, CG with less than two animals, and sires with less than three offspring were excluded. The significant $(P<0.01)$ fixed terms included in the genetic models for each trait are presented in Table 1.

The season of birth was defined as spring (SeptemberNovember), summer (December-February), autumn (MarchMay) and winter (June-August). The diet at weaning and yearling consisted of five classes (pasture, fertilised pasture, fertilised and rotational pasture, irrigated pasture, and feedlot). Genetic groups were defined for the Canchim and MA animals. Observations for which the standardised residuals (normalised data obtained by the $\mathrm{z}$-scores statistic) were greater than 3.5 or lower than -3.5 , (which correspond to $0.22 \%$ of the data for each trait) were considered outliers and excluded. The descriptive statistics of the evaluated traits after data quality control are presented in Table 2.

\section{Genetic parameters}

The genetic parameters were estimated by Average Information Restricted Maximum Likelihood method under an animal model (single and multi-trait analyses). The total number of animals in the relationship matrix was 20041 . Analyses were conducted using the software WOMBAT (Meyer 2007) using the convergence criterion of $10^{-9}$.

The inclusion of maternal genetic and/or maternal permanent environmental random effects was previously evaluated for bodyweight and scrotal circumference traits using the likelihood ratio test (Dobson 1990). Due to limited pedigree structure, the statistical model for BW, WW, and SCW was extended to include the additive genetic, maternal genetic, and

Table 1. Significant $(P<0.01)$ fixed terms and coefficient of determination $\left(R^{2}\right)$ included in the genetic models for each trait BW, birthweight; WW, weaning weight; YW, yearling weight; SCW, scrotal circumference at weaning; SCY, scrotal circumference at yearling; $\mathrm{AFC}$, age at first calving; REA, ribeye area; BFT, back fat thickness; $(+)$, fixed effect considered in the contemporary group; *, linear effect; $* *$, linear-quadratic effect

\begin{tabular}{|c|c|c|c|c|c|c|c|c|}
\hline \multirow[t]{3}{*}{ Effects } & \multicolumn{8}{|c|}{ Traits } \\
\hline & BW & WW & YW & SCW & SCY & $\mathrm{AFC}$ & REA & BFT \\
\hline & \multicolumn{8}{|c|}{ Fixed effects considered in the contemporary groups } \\
\hline Sex & + & + & + & - & - & - & + & + \\
\hline Year of birth & + & + & + & + & + & + & + & + \\
\hline Season of birth & + & - & - & - & - & - & - & - \\
\hline Farm of birth & + & + & + & + & + & + & + & + \\
\hline Farm at weaning & - & + & + & + & + & + & + & + \\
\hline Farm at yearling & - & - & + & - & + & + & + & + \\
\hline Diet at weaning & - & + & - & + & - & - & - & - \\
\hline Diet at yearling & - & - & + & - & + & - & + & + \\
\hline \multirow[t]{2}{*}{ Genetic group } & - & + & + & + & + & + & + & + \\
\hline & \multicolumn{8}{|c|}{ Covariates } \\
\hline Age of the dam at calving** & + & + & + & + & - & - & - & - \\
\hline Age at weaning* & - & + & - & + & - & - & - & - \\
\hline Age at yearling* & - & - & + & - & + & - & - & - \\
\hline \multirow[t]{3}{*}{ Age at ultrasound measurement* } & - & - & - & - & - & - & + & + \\
\hline & \multicolumn{8}{|c|}{ Coefficient of determination $\left(R^{2}\right)$} \\
\hline & 0.37 & 0.53 & 0.73 & 0.39 & 0.28 & 0.39 & 0.81 & 0.61 \\
\hline
\end{tabular}


Table 2. Descriptive statistics on the resulting unadjusted values after data quality control and statistical modelling for bodyweight, reproductive, and carcass traits. The unadjusted values were used for genetic analysis of the traits considered

BW, birthweight; WW, weaning weight; YW, yearling weight; SCW, scrotal circumference at weaning; SCY, scrotal circumference at yearling; AFC, age at first calving; REA, ribeye area; BFT, back fat thickness; CG, contemporary groups; CV, coefficient of variation; $R^{2}$, coefficient of determination

\begin{tabular}{lccccrrrrr}
\hline Traits & $\begin{array}{c}\text { Number of } \\
\text { animals }\end{array}$ & $\begin{array}{c}\text { Number of } \\
\text { males }\end{array}$ & $\begin{array}{c}\text { Number of } \\
\text { sires }\end{array}$ & $\begin{array}{c}\text { Number of } \\
\text { dams }\end{array}$ & $\begin{array}{c}\text { Number of } \\
\text { CG }\end{array}$ & $\begin{array}{c}\text { Average } \\
\text { CV (\%) }\end{array}$ & $\begin{array}{c}\text { Minimum } \\
\text { values }\end{array}$ & $\begin{array}{c}\text { Maximum } \\
\text { values }\end{array}$ \\
\hline BW (kg) & 12967 & 1901 & 362 & 7634 & 936 & 34.70 & 13.79 & 15.00 \\
WW (kg) & 7481 & 1730 & 323 & 4656 & 736 & 202.00 & 18.07 & 94.00 & 326.00 \\
YW (kg) & 5131 & 1365 & 312 & 3427 & 609 & 305.00 & 20.93 & 127.00 & 514.00 \\
SCW (cm) & 1447 & - & 204 & 996 & 113 & 18.70 & 11.94 & 12.50 & 26.00 \\
SCY (cm) & 1224 & - & 230 & 980 & 86 & 29.20 & 10.81 & 20.00 \\
AFC (months) & 1400 & - & 177 & 1225 & 208 & 36.65 & 13.99 & 25.60 \\
REA (cm $\left.{ }^{2}\right)$ & 2082 & 1077 & 257 & 1422 & 189 & 53.00 & 27.63 & 21.46 & 52.39 \\
BFT (mm) & 2082 & 1077 & 257 & 1422 & 189 & 2.20 & 34.60 & 0.60 \\
\hline
\end{tabular}

Table 3. Variance components and heritability estimates obtained in single-trait analyses BW, birthweight; WW, weaning weight; YW, yearling weight; SCW, scrotal circumference at weaning; SCY, scrotal circumference at yearling; AFC, age at first calving; REA, ribeye area; BFT, back fat thickness; $\sigma_{a}^{2}$, additive genetic variance; $\sigma_{m}^{2}$, additive maternal variance; $\sigma_{e}^{2}$, environmental variance; $\sigma_{p}^{2}$, phenotypic variance; $h_{a}^{2}$, direct heritability estimate; $h_{m}^{2}$, maternal heritability estimate; s.e., standard error

\begin{tabular}{lrrrrrr}
\hline Traits & \multicolumn{5}{c}{ Variance components and heritability estimates } \\
& \multicolumn{1}{c}{$\sigma_{a}^{2}$} & $\sigma_{m}^{2}$ & \multicolumn{1}{c}{$\sigma_{e}^{2}$} & $\sigma_{p}^{2}$ & $h_{a}^{2} \pm$ s.e. & $h_{m}^{2} \pm$ s.e. \\
\hline BW & 4.36 & 1.34 & 10.23 & 15.94 & $0.27 \pm 0.03$ & $0.08 \pm 0.01$ \\
WW & 169.04 & 138.06 & 420.18 & 727.29 & $0.23 \pm 0.03$ & $0.19 \pm 0.02$ \\
YW & 360.13 & - & 863.00 & 1223.14 & $0.29 \pm 0.04$ & - \\
SCW & 0.97 & 0.21 & 2.10 & 3.29 & $0.29 \pm 0.08$ & $0.06 \pm 0.04$ \\
SCY & 3.36 & - & 4.55 & 7.92 & $0.42 \pm 0.10$ & - \\
AFC & 1.88 & - & 17.14 & 19.02 & $0.09 \pm 0.07$ & - \\
REA & 15.62 & - & 29.04 & 44.67 & $0.35 \pm 0.06$ & - \\
BFT & 0.05 & - & 0.19 & 0.24 & $0.20 \pm 0.06$ & - \\
\hline
\end{tabular}

residual random effects; and the fixed effects of $\mathrm{CG}$ and covariates. The statistical model for YW, SCY, AFC, REA, and BFT included the additive genetic and residual random effects, as well as the fixed effects of $\mathrm{CG}$ and covariates. Residual covariances between traits measured on opposite sex were set to zero.

\section{Results and discussion}

The observed average for bodyweight, reproductive, and carcass traits (Table 2) are in agreement with previous studies of the Canchim breed (Andrade et al. 2008; Baldi et al. 2010; Barichello et al. 2010; Buzanskas et al. 2010; Meirelles et al. 2010; Borba et al. 2011). The variance components and heritabilities estimated in single-trait analyses are presented in Table 3. A substantial proportion of the variation in the bodyweights, scrotal circumferences and carcass traits was associated with the additive genetic term indicating that these traits may respond to selection in Canchim cattle.

For BW, WW, YW, and SCW the direct heritability estimates were in the range found in the literature for the Canchim breed, which ranged from 0.25 to 0.41 (BW), 0.23 to 0.48 (WW), 0.24 to 0.29 (YW), and 0.17 to 0.52 (SCW) (Alencar et al. 1993; Silva et al. 2000; Gianlorenço et al. 2003; Andrade et al. 2008; Baldi et al. 2010; Buzanskas et al. 2010; Borba et al. 2011). Direct heritability estimates for BW obtained by Boligon et al. (2011), El-Saied et al. (2006), and Meyer (1995) were equal to $0.30 \pm$ $0.01,0.36 \pm 0.04$, and 0.38 for Nellore, Charolais, and Australian Angus cattle. Boligon et al. (2010), Meyer (1993), and Meyer (1995) estimated direct heritability in Nellore, Charolais, and Australian Angus of $0.33 \pm 0.02,0.13$, and $0.23 \pm 0.01$, for WW; and $0.37 \pm 0.03,0.32,0.31 \pm 0.01$, for YW.

For SCW, Boligon et al. (2011) and Morris et al. (2000) found heritability estimates of $0.39 \pm 0.01$ and $0.37 \pm 0.06$, respectively for Nellore and Angus breeds. Alencar et al. (1993) and Borba et al. (2011) found lower heritability estimates for SCY in Canchim. According to Silva et al. (2013a) and Garmyn et al. (2011), heritability estimates for SCY in Nellore and Angus, respectively, were equal to $0.40 \pm 0.02$ and $0.46 \pm 0.08$

The heritability estimates for REA and BFT are in agreement with the ones obtained by Meirelles et al. (2010) in Canchim cattle. Heritability estimates varying from 0.18 to 0.68 , for BFT, and from 0.29 to 0.64 , for REA, were described for Simmental (Crews et al. 2003), Charolais (Chen et al. 2014), Guzerat (Lima Neto et al. 2009), and Nellore (Yokoo et al. 2010; Zuin et al. 2012). 
Buzanskas et al. (2010) and Borba et al. (2011) found heritability estimates of $0.04 \pm 0.01$ and $0.05 \pm 0.02$ for $\mathrm{AFC}$, respectively, using Bayesian methodology. Under the restricted maximum likelihood method, Baldi et al. (2008) and Silva et al. (2000) found heritability estimates equal to $0.10 \pm 0.05$ and 0.12 , respectively, slightly larger than our estimate of 0.09 obtained in single-trait analysis. The age at which heifers are exposed to the bulls is very challenging when evaluating AFC. Heifers that have early oestrus cannot be detected if not exposed, thus the variability of the trait could be influenced by non-genetic factors.

The maternal genetic effect was estimated for BW, WW, and $\mathrm{SCW}$, respectively. The results for maternal heritability estimate for WW and SCW indicates that this effect could influence the performance of WW traits (Meyer 1992), however there has been some evidence for maternal effects on post-weaning growth (Mackinnon et al. 1991). In our study, the average number of calves per dam was equal to $1.69,1.60$, and 1.45, for BW, WW, and SCW, respectively. According to Pelicioni et al. (2003), the presence of cows with a low number of calves may present confounded effects between maternal genetic and maternal permanent environmental random effects when genetic evaluations are conducted.

The heritability estimates and genetic correlations obtained in multi-trait analysis are presented in Table 4. Due to the (co) variance structure considered in the multi-trait analysis, greater variation in the heritabilities estimates (direct and maternal) was observed for WW in comparison to the single-trait analysis. All other traits presented similar results in each analysis.

The genetic correlations among bodyweight traits were from 0.41 to 0.93 , suggesting pleiotropic effects, especially between WW and YW. These estimates were similar to those presented by Baldi et al. (2010) in Canchim cattle. High genetic correlations among bodyweight traits were observed by Vargas et al. (2014), Neser et al. (2012), and Van Niekerk and Neser (2006) for Brahman, Brangus, and Limousin breeds. Silva et al. (2013b) estimated genetic correlations for Nellore cattle from birth to 550 days of age, which varied from 0.25 to 0.98 . Selection of any of these traits would increase bodyweight gains at later ages.
The genetic correlation between SCW and SCY was high (0.91). Boligon et al. (2010) obtained genetic correlations of $0.80 \pm 0.02$ among scrotal circumferences measured at 9 and 18 months of age in Nellore cattle. High genetic correlations were observed between SCW and WW, and SCY and YW. For the Nellore breed, Boligon et al. (2010) obtained genetic correlations for scrotal circumference and bodyweight traits lower than ours. Selection to increase SCW or SCY will contribute positively and indirectly to bodyweight of Canchim animals. The genetic correlation between WW and SCW estimated by Barichello et al. (2010) in Canchim cattle was lower than ours.

Most of the genetic correlations with AFC were favourable, especially with YW, SCW, and SCY $(-0.48,-0.61$ and -0.71 , respectively), which suggests indirect and favourable responses to selection. Similar genetic correlations among these traits were observed in the Canchim breed (Talhari et al. 2003; Borba et al. 2011) and Nellore breed (Barrozo et al. 2012; Chiaia et al. 2015). The genetic correlation between AFC and BFT $(-0.69)$ indicated that selection for high fat deposition could result in lower ages at first calving. From a biological point of view, this favourable correlation could be due to the lipid production or fat deposition, which is directly linked to hormonal production and sexual development (Dias et al. 2009). According to Caetano et al. (2013), the genetic correlation between AFC and BFT was equal to $-0.35 \pm 0.08$ in the Nellore breed.

The REA presented low to moderate genetic correlations with BW, WW, and YW. The genetic correlation among these traits increases as animals grow older, possibly due to muscular development, suggesting that selection for bodyweight could improve this carcass trait. For the Nellore breed, Yokoo et al. (2010) and Zuin et al. (2012) estimated genetic correlations of $0.69 \pm 0.06$ and $0.62 \pm 0.02$ between REA and WW, respectively. Meirelles et al. (2010) and Gordo et al. (2012) observed a genetic correlation of $0.62 \pm 0.16$ and $0.55 \pm 0.04$ between YW and REA in Canchim and Nellore cattle. The opposite trend was observed between REA with SCW and SCY, in which SCY resulted in a genetic correlation close to zero. Thus, REA and scrotal circumferences appear to be independent

Table 4. Direct and maternal heritability estimates (diagonal, in bold) and genetic correlations (above diagonal) with respective standard errors ( $₫$ ) obtained from multi-trait analysis

BW, birthweight; WW, weaning weight; YW, yearling weight; SCW, scrotal circumference at weaning; SCY, scrotal circumference at yearling; AFC, age at first calving; REA, ribeye area; BFT, back fat thickness

\begin{tabular}{|c|c|c|c|c|c|c|c|c|}
\hline Traits & BW & WW & YW & SCW & SCY & AFC & REA & BFT \\
\hline BW & $\begin{array}{l}0.26 \pm 0.03^{A} \\
0.07 \pm 00.01^{B}\end{array}$ & $0.42 \pm 0.07$ & $0.41 \pm 0.07$ & $0.07 \pm 0.11$ & $0.09 \pm 0.10$ & $0.14 \pm 0.21$ & $0.25 \pm 0.11$ & $0.18 \pm 0.13$ \\
\hline WW & - & $\begin{array}{l}\mathbf{0 . 3 5} \pm \mathbf{0 . 0 3}^{\mathrm{A}} \\
\mathbf{0 . 0 8} \pm \mathbf{0 . 0 1}^{\mathrm{B}}\end{array}$ & $0.93 \pm 0.02$ & $0.52 \pm 0.09$ & $0.43 \pm 0.09$ & $-0.23 \pm 0.25$ & $0.62 \pm 0.09$ & $0.38 \pm 0.14$ \\
\hline YW & - & - & $0.32 \pm 0.04^{\mathrm{A}}$ & $0.59 \pm 0.09$ & $0.47 \pm 0.10$ & $-0.48 \pm 0.27$ & $0.49 \pm 0.11$ & $0.43 \pm 0.16$ \\
\hline SCW & - & - & - & $\begin{array}{l}0.32 \pm \mathbf{0 . 0 6}^{\mathrm{A}} \\
\mathbf{0 . 0 6} \pm \mathbf{0 . 0 2}^{\mathrm{B}}\end{array}$ & $0.91 \pm 0.06$ & $-0.61 \pm 0.39$ & $0.09 \pm 0.17$ & $0.14 \pm 0.20$ \\
\hline SCY & - & - & - & - & $0.49 \pm 0.08^{\mathrm{A}}$ & $-0.71 \pm 0.34$ & $-0.02 \pm 0.17$ & $0.15 \pm 0.19$ \\
\hline AFC & - & - & - & - & - & $0.11 \pm 0.07^{\mathrm{A}}$ & $0.30 \pm 0.32$ & $-0.69 \pm 0.35$ \\
\hline REA & - & - & - & - & - & - & $0.35 \pm 0.07^{\mathrm{A}}$ & $0.27 \pm 0.17$ \\
\hline BFT & - & - & - & - & - & - & - & $0.21 \pm 0.06^{\mathrm{A}}$ \\
\hline
\end{tabular}

${ }^{\mathrm{A}}$ Direct heritability estimate.

${ }^{\mathrm{B}}$ Maternal heritability estimate. 
Table 5. Environmental (above diagonal) and phenotypic (below diagonal) correlations obtained by multi-trait analysis BW, birthweight; WW, weaning weight; YW, yearling weight; SCW, scrotal circumference at weaning; SCY, scrotal circumference at yearling; AFC, age at first calving; REA, ribeye area; BFT, back fat thickness

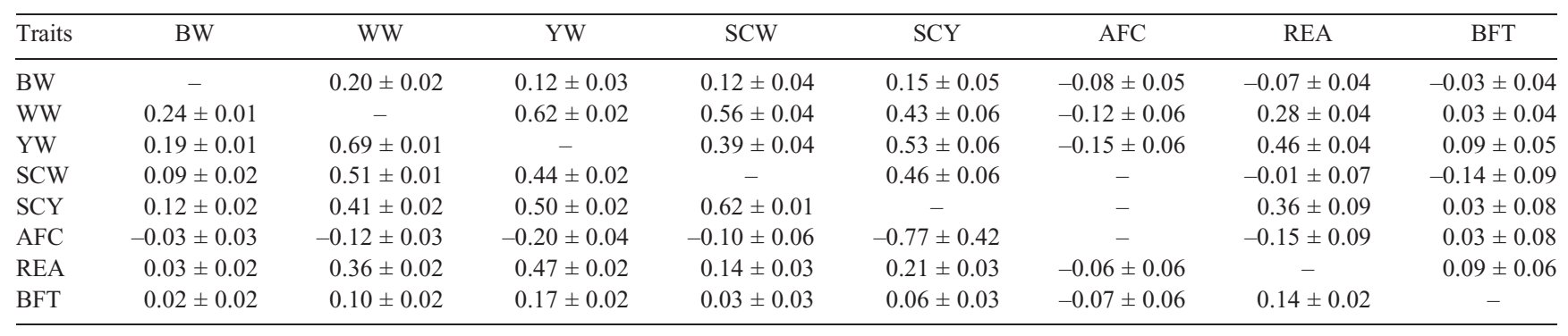

traits. Marques et al. (2013) found low genetic correlation of scrotal circumference with REA in the Nellore breed.

Moderate genetic correlation between REA and AFC was observed. As the age at calving increases, an increase in bodyweight is expected. This indicates that females with higher REA may calve later in life; however, a high standard error was obtained for this genetic correlation. Caetano et al. (2013) observed a genetic correlation of $-0.11 \pm 0.04$ between REA and AFC. The BFT presented moderate genetic correlation with WW and YW, whereas for the scrotal circumferences and BW it presented correlations of low magnitude. This indicates that at post-weaning ages the fat deposition could be beginning. For Brangus and Nellore breeds, Stelzleni et al. (2002) and Yokoo et al. (2010), respectively, found similar genetic correlations between BFT and YW.

Low and positive genetic correlations were observed among carcass traits, indicating no linear association and if selection were carried out, there would be minor changes expected among them. Similar results were observed by Meirelles et al. (2010), Chen et al. (2014), and Caetano et al. (2013) between REA and BFT, equal to $0.21 \pm 0.24,0.19 \pm 0.18$, and $0.19 \pm 0.06$, for Canchim, Charolais, and Nellore breeds, respectively. Peters et al. (2014), using multivariate normal distribution analysis, obtained genetic correlation between REA and BFT equal to $-0.41 \pm 0.30$ in beef cattle.

The environmental and phenotypic correlations obtained in multi-trait analysis are presented in Table 5. Environmental correlations between $\mathrm{BW}$ and $\mathrm{AFC}, \mathrm{BW}$ and REA, BW and BFT, SCW and AFC, SCW and REA, SCW and BFT, SCY and REA, AFC and REA, and AFC and BFT presented opposite signs and similar magnitudes with the genetic correlations. The opposite signs indicate that genetic and environmental sources of variation affect the traits by means of different physiological mechanisms (Falconer and Mackay 1996).

\section{Conclusion}

Genetic improvement through selection is expected for production, reproduction, and carcass traits in Canchim beef cattle. Many of the traits considered in the genetic evaluation of this breed are genetically correlated in a favourable manner. Genetic parameter estimates indicate that improvement for carcass and reproduction traits could be achieved.

\section{Acknowledgements}

Bruno Carlos Pires, Ana Paula Sbardella, and Jaqueline Oliveira Rosa would like to acknowledge CAPES ('Coordenação de Aperfeiçoamento de Pessoal de Nível Superior') for the grant received. Danísio Prado Munari and Maurício Mello de Alencar were supported by a fellowship from $\mathrm{CNPq}$ ('Conselho Nacional de Desenvolvimento Científico e Tecnológico'). Marcos Eli Buzanskas would like to thank the 'Fundação de Amparo à Pesquisa do Estado de São Paulo’ (FAPESP) (grantee no. 13/19335-2).

\section{References}

ABCCAN-Embrapa-Geneplus (2015) Sumário de touros Canchim, MA e Charolês, Edição Outono/2015. Available at http://geneplus.cnpgc. embrapa.br/sumarios/canchim/index.php?tp=conceitos

Alencar MM, Barbosa PF, Barbosa RT, Vieira RC (1993) Parâmetros genéticos para peso e circunferência escrotal em touros da raça Canchim. Revista Brasileira de Zootecnia 22, 572-583.

Andrade PC, Grossi DA, Paz CCP, Alencar MM, Regitano LCA, Munari DP (2008) Association of an insulin-like growth factor 1 gene microsatellite with phenotypic variation and estimated breeding values of growth traits in Canchim cattle. Animal Genetics 39, 480-485. doi:10.1111/j.13652052.2008.01755.x

Baldi F, Alencar MM, Freitas AR, Barbosa RT (2008) Parâmetros genéticos para características de tamanho e condição corporal, eficiência reprodutiva e longevidade em fềmeas da raça Canchim. Revista Brasileira de Zootecnia 37, 247-253. doi:10.1590/S1516-3598200800 0200010

Baldi F, Alencar MM, Albuquerque LG (2010) Estimativas de parâmetros genéticos para características de crescimento em bovinos da raça Canchim utilizando modelos de dimensão finita. Revista Brasileira de Zootecnia 39, 2409-2417. doi:10.1590/S1516-35982010001100013

Barichello F, Alencar MM, Torres Júnior RAA, Silva LOC (2010) Herdabilidade e correlações quanto a peso, perímetro escrotal e escores visuais à desmama, em bovinos Canchim. Pesquisa Agropecuaria Brasileira 45, 563-570.

Barrozo D, Buzanskas ME, Oliveira JA, Munari DP, Neves HHR, Queiroz SA (2012) Genetic parameters and environmental effects on temperament score and reproductive traits of Nellore cattle. Animal 6, 36-40. doi:10.1017/S1751731111001169

Boligon AA, Silva JAV, Sesana RC, Sesana JC, Junqueira JB, Albuquerque LG (2010) Estimation of genetic parameters for body weights, scrotal circumference, and testicular volume measured at different ages in Nellore cattle. Journal of Animal Science 88, 1215-1219. doi:10.2527/jas.20081719

Boligon AA, Baldi F, de Albuquerque LG (2011) Genetic parameters and relationships between growth traits and scrotal circumference measured at 
different ages in Nellore cattle. Genetics and Molecular Biology 34, 225-230. doi:10.1590/S1415-47572011005000004

Borba LHF, Rey FSB, Silva LOC, Boligon AA, Alencar MM (2011) Parâmetros genéticos para características de crescimento e reprodução de bovinos da raça Canchim. Pesquisa Agropecuaria Brasileira 46, 1570-1578. doi:10.1590/S0100-204X2011001100020

Brumatti RC, Ferraz JBS, Eler JP, Formigoni IB (2011) Desenvolvimento de índice de seleção em gado corte sob o enfoque de um modelo bioeconômico. Archivos de Zootecnia 60, 205-213. doi:10.4321/ S0004-05922011000200005

Buzanskas ME, Grossi DA, Baldi F, Barrozo D, Silva LOC, Torres Júnior RAA, Munari DP, Alencar MM (2010) Genetic associations between stayability and reproductive and growth traits in Canchim beef cattle. Livestock Science 132, 107-112. doi:10.1016/j.livsci.2010.05.008

Caetano SL, Savegnago RP, Boligon AA, Ramos SB, Chud TCS, Lôbo RB, Munari DP (2013) Estimates of genetic parameters for carcass, growth and reproductive traits in Nellore cattle. Livestock Science 155, 1-7. doi:10.1016/j.livsci.2013.04.004

Chiaia HLJ, de Lemos MVA, Venturini GC, Aboujaoude C, Berton MP, Feitosa FB, Carvalheiro R, Albuquerque LG, de Oliveira HN, Baldi F (2015) Genotype $\times$ environment interaction for age at first calving, scrotal circumference, and yearling weight in Nellore cattle using reaction norms in multitrait random regression models. Journal of Animal Science 93, 1503-1510. doi:10.2527/jas.2014-8217

Chen L, Mao F, Crews DH, Vinsky M, Li C (2014) Phenotypic and genetic relationships of feeding behavior with feed intake, growth performance, feed efficiency, and carcass merit traits in Angus and Charolais steers. Journal of Animal Science 92, 974-983. doi:10.2527/jas.2013-6926

Crews DH Jr, Pollak RL, Weaber RL, Quaas RL, Lipsey RJ (2003) Genetic parameters for carcass traits and their live animal indicators in Simmental cattle. Journal of Animal Science 81, 1427-1433.

Dias JC, Martins JAM, Emerick LL, Souza FA, Andrade VJ (2009) Efeitos da suplementação lipídica no aumento da eficiência reprodutiva de fêmeas bovinas. Revista Brasileira de Reprodução Animal 33, 95-104.

Dobson AJ (1990) 'An introduction to generalized linear models.' (Chapman and Hall: Melbourne)

El-Saied UM, de la Fuente LF, Rodriguez R, San Primitivo F (2006) Genetic parameter estimates for birth and weaning weights, pre-weaning daily weight gain and three type traits for Charolais beef cattle in Spain. Spanish Journal of Agricultural Research 4, 146-155. doi:10.5424/sjar/2006042186

Falconer DS, Mackay TFC (1996) 'Introduction to quantitative genetics.' (Pearson Prentice Hall: Essex, England)

Garmyn AJ, Moser DW, Christmas RA, Minick Bormann J (2011) Estimation of genetic parameters and effects of cytoplasmic line on scrotal circumference and semen quality traits in Angus bulls. Journal of Animal Science 89, 693-698. doi:10.2527/jas.2010-3534

Gianlorenço VK, Alencar MM, Toral FLB, Mello SP, Freitas AR, Barbosa PF (2003) Herdabilidades e Correlações Genéticas de Características de Machos e Fêmeas, em um Rebanho Bovino da Raça Canchim. Revista Brasileira de Zootecnia 32, 1587-1593. doi:10.1590/S1516-3598200 3000700007

Gordo DGM, Baldi F, Lôbo RB, Filho WK, Sainz RD, Albuquerque LG (2012) Genetic association between body composition measured by ultrasound and visual scores in Brazilian Nelore cattle. Journal of Animal Science 90, 4223-4229. doi:10.2527/jas.2011-3935

Krupa E, Wolfová M, Peškovičová D, Huba J, Krupová Z (2005) Economic values of traits for Slovakian Pied cattle under different marketing strategies. Czech Journal of Animal Science 50, 483-492.

Lima Neto HR, Bergmann JAG, Gonçalves TM, Araújo FRC, Bezerra LAF, Saiz RD, Lôbo RB, Silva MA (2009) Parâmetros genéticos para características de carcaça avaliadas por ultrassonografia em bovinos da raça Guzerá. Arquivo Brasileiro de Medicina Veterinária e Zootecnia 61, 251-258. doi:10.1590/S0102-09352009000100035
Luchiari Filho A (2000) 'Pecuária da carne bovina.' (Ed. Albino Luchiari Filho) (LimBife: São Paulo-SP)

Mackinnon M, Meyer K, Hetzel DJ (1991) Genetic variation and covariation for growth, parasite resistance and heat tolerance in tropical cattle. Livestock Production Science 27, 105-122. doi:10.1016/0301-6226 (91)90090-D

Marques EG, Magnabosco CU, Lopes FB, Silva MC (2013) Estimativas de parâmetros genéticos de características de crescimento, carcaça e perímetro escrotal de animais da raça Nelore avaliados em provas de ganho em peso em confinamento. Bioscience Journal 29, 159-167.

Meirelles SL, Alencar MM, Oliveira HN, Regitano LCA (2010) Efeitos de ambiente e estimativas de parâmetros genéticos para características de carcaça em bovinos da raça Canchim criados em pastagem. Revista Brasileira de Zootecnia 39, 1437-1442. doi:10.1590/S1516-359820100 00700006

Meyer K (1992) Variance components due to direct and maternal effects for growth traits of Australian beef cattle. Livestock Production Science 31, 179-204. doi:10.1016/0301-6226(92)90017-X

Meyer K (1993) Estimates of covariance components for growth traits of Australian Charolais cattle. Australian Journal of Agricultural Research 44, 1501-1508. doi:10.1071/AR9931501

Meyer K (1995) Estimates of genetic parameters and breeding values for New Zealand and Australian Angus cattle. Australian Journal of Agricultural Research 46, 1219-1229. doi:10.1071/AR9951219

Meyer K (2007) WOMBAT: a tool for mixed model analyses in quantitative genetics by restricted maximum likelihood (REML). Journal of Zhejiang University. Science. B. 8, 815-821. doi:10.1631/jzus.2007.B0815

Morris CA, Wilson JA, Bennett GL, Cullen NG, Hickey SM, Hunter JC (2000) Genetic parameters for growth, puberty, and beef cow reproductive traits in a puberty selection experiment. New Zealand Journal of Agricultural Research 43, 83-91. doi:10.1080/00288233.2000.9513411

Neser FWC, Van Wyk JB, Fair MD, Lubout P, Crook BJ (2012) Estimation of genetic parameters for growth traits in Brangus cattle. South African Journal of Animal Science 42, 469-473.

Pelicioni LC, Queiroz SA, Albuquerque LG (2003) Estimativas de parâmetros genéticos para pesos ao nascer e mensais até 450 dias em bovinos Guzerá. Archivos Latinoamericanos de Produción Animal 11, 34-39.

Peters SO, Kizilkaya K, Garrick DJ, Fernando RL, Pollak EJ, Enns RM, De Donato M, Ajayi OO, Imumorin IG (2014) Use of robust multivariate linear mixed models for estimation of genetic parameters for carcass traits in beef cattle. Journal of Animal Breeding and Genetics 131, 504-512. doi:10.1111/jbg. 12093

Silva AM, Alencar MM, Freitas AR, Barbosa RT, Barbosa PF, Oliveira MCS, Corrêa LA, Novaes AP, Tullio RR (2000) Herdabilidades e Correlações Genéticas para Peso e Perímetro Escrotal de Machos e Características Reprodutivas e de Crescimento de Fêmeas, na Raça Canchim. Revista Brasileira de Zootecnia 29, 2223-2230.

Silva MR, Pedrosa VB, Borges-Silva JC, Eler JP, Guimaraes JD, Albuquerque LG (2013a) Genetic parameters for scrotal circumference, breeding soundness examination and sperm defects in young Nellore bulls. Journal of Animal Science 91, 4611-4616. doi:10.2527/jas.2012-6067

Silva TBR, Araújo CV, Bittencourt TCBSC, Araújo SI, Lôbo RB, Bezerra LAF, Silva AA (2013b) Use of orthogonal functions in random regression models in describing genetic variance in Nellore cattle. Revista Brasileira de Zootecnia 42, 254-258. doi:10.1590/S1516-35982013000400004

Stelzleni AM, Perkins TL, Brown AH Jr, Pohlman FW, Johnson ZB, Sandelin B (2002) Genetic parameter estimates of yearling live animal ultrasonic measurements in Brangus cattle. Journal of Animal Science 80, 3150-3153.

Talhari FM, Alencar MM, Mascioli AS, Silva AM, Barbosa PF (2003) Correlações Genéticas entre Características Produtivas de Fêmeas em um Rebanho da Raça Canchim. Revista Brasileira de Zootecnia 32, 880-886. doi:10.1590/S1516-35982003000400013 
Van Niekerk M, Neser FWC (2006) Genetic parameters for growth traits in South African Limousin cattle. South African Journal of Animal Science 36, 2004-2007.

Vargas G, Buzanskas ME, Guidolin DGF, Grossi DA, Bonifácio AS, Lôbo RB, Fonseca R, Oliveira JA, Munari DP (2014) Genetic parameter estimation for pre- and post-weaning traits in Brahman cattle in Brazil. Tropical Animal Health and Production 46, 1271-1278. doi:10.1007 s11250-014-0640-3
Yokoo MJ, Lobo RB, Araujo FRC, Bezerra LAF, Sainz RD, Albuquerque LG (2010) Genetic associations between carcass traits measured by real-time ultrasound and scrotal circumference and growth traits in Nelore cattle. Journal of Animal Science 88, 52-58. doi:10.2527/jas.2008-1028

Zuin RG, Buzanskas ME, Caetano SL, Venturini GC, Guidolin DGF, Grossi DA, Chud TCS, Paz CCP, Lôbo RB, Munari DP (2012) Genetic analysis on growth and carcass traits in Nelore cattle. Meat Science 91, 352-357. doi:10.1016/j.meatsci.2012.02.018 